\title{
Analisis Sentimen Movie Review menggunakan Word2Vec dan metode LSTM Deep Learning
}

\author{
Widi Widayat" \\ Fakultas Informatika, Program Studi Informatika, Institut Teknologi Telkom Purwokerto, Purwokerto, Indonesia \\ Email: widi@ittelkom-pwt.ac.id \\ Email Penulis Korespondensi: widi@ittelkom-pwt.ac.id
}

\begin{abstract}
Abstrak-Peningkatan jumlah pengguna internet sejalan dengan peningkatan jumlah data di internet yang tersedia untuk bisa dianalisis, khususnya data dalam bentuk teks. Ketersediaan data teks ini mendorong penelitian analisis sentimen banyak dilakukan. Namun ternyata ketersediaan data teks yang melimpah tersebut juga menjadi salah satu tantangan tersendiri dalam penelitian analisis sentimen. Dataset yang terdiri dari dokumen teks yang relatif panjang dan kompleks memerlukan pendekatan yang berbeda. Pada penelitian ini, LSTM dipilih untuk digunakan sebagai metode klasifikasi sentimen. Dataset yang digunakan adalah dataset movie review yang terdiri dari 25.000 dokumen review, dengan panjang rata-rata per review adalah 233 kata. Penelitian menggunakan metode CBOW dan Skip-Gram pada word2vec untuk membentuk vektor representasi dari setiap kata (word vector) di corpus. Beberapa ukuran dimensi dari word vector yaitu dimensi 50, 60, 100, 150, 200 dan 500 digunakan, untuk mengetahui pengaruhnya terhadap akurasi yang dihasilkan. Akurasi terbaik diperoleh pada ukuran dimensi word vector 100 sebesar $88.17 \%$ dan akurasi terendah sebesar $85.86 \%$ pada ukuran dimensi word vector 500 .
\end{abstract}

Kata Kunci: Sentimen; Klasifikasi; RNN; LSTM; word2vec

Abstract-The increasing number of internet users is directly in line with the increasing number of data on the internet that is available for analysis, especially data in text form. The availability of this text data encourages a lot of sentiment analysis research. However, it turns out that the availability of abundant text data is also one of the challenges in sentiment analysis research. Datasets that consist of long and complex text documents require a different approach. In this study, LSTM was chosen to be used as a sentiment classification method. This research uses a movie review dataset that consists of 25,000 review documents, with an average length per review is 233 words. The research uses CBOW and Skip-Gram methods on word2vec to form a vector representation of each word (word vector) in the corpus data. Several dimensions of the word vector was used in this research, there are 50,60,100,150,200, and 500, this tuning parameter is used to determine their effect on the resulting accuracy. The best accuracy around $88.17 \%$ is obtained at the word vector 100 dimension and the lowest accuracy is $85.86 \%$ at the word vector 500 dimension.

Keywords: Sentiment; Classification; RNN; LSTM; word2vec

\section{PENDAHULUAN}

Sejak memasuki era digital, terjadi peningkatan jumlah pengguna internet di dunia yang signifikan. Peningkatan jumlah pengguna internet tersebut selaras dengan peningkatan jumlah data yang tersedia di internet. Ketersediaan data yang melimpah di internet, terutama data teks telah mendorong banyak penelitian mengenai topik text mining maupun NLP (Natural Languange Processing). Salah satu penelitian NLP yang populer adalah penelitian analisis sentimen [1], [2]. Analisis sentimen merupakan proses komputasi untuk melakukan klasifikasi terhadap data tekstual sesuai dengan sentimen yang dimiliki. Selain alasan ketersediaan data teks yang melimpah saat ini, penelitian analisis sentimen semakin populer karena alasan kebutuhan dari banyak pihak mengenai pendapat publik terhadap suatu topik tertentu. Proses analisis sentimen dipengaruhi oleh dataset yang digunakan. Untuk dataset yang terdiri dari kumpulan kalimat yang cukup panjang membutuhkan penanganan yang berbeda.

Dalam beberapa tahun terakhir penelitian mengenai analisis sentimen telah banyak dilakukan. Pendekatan atau metode yang sering digunakan adalah metode machine learning tradisional seperti metode Lexicon based, Nä̈ve Bayes, Maximum Entropy maupun metode SVM (Support Vector Machine) [1], [3]. Penelitian analisis sentimen yang dilakukan oleh Pang et al, menggunakan metode Nä̈ve Bayes, Maximum Entropy classification dan SVM pada dataset Movie Review [4]. Lalu penelitian analisis sentimen yang selanjutnya, adalah penelitian oleh Dang et al yang menggunakan metode SVM pada dataset online product review [5]. Atau penelitian yang dilakukan oleh Saleh et al, yang juga menggunakan metode SVM untuk melakukan klasifikasi sentimen pada beberapa domain dataset, yaitu dataset dari penelitian Pang et al, dataset penelitian Taboada dan juga dataset oleh crawling website Amazon [6]. Dari beberapa penelitian analisis sentimen yang telah dijabarkan, metode SVM menjadi metode yang paling banyak digunakan. Hal ini karena akurasi yang dihasilkan oleh metode SVM pada kasus klasifikasi sentimen lebih bagus dibandingkan metode machine learning yang lain, seperti Nä̈ve Bayes maupun Maximum entropy classification [4]-[6].

Selain menggunakan metode machine learning yang sudah disebutkan di atas, penelitian analisis sentimen juga mulai banyak dilakukan dengan menggunakan metode deep learning. Deep learning menjadi semakin populer, salah satu alasannya adalah karena saat menggunakan dataset dalam jumlah yang besar dan kompleks, metode machine learning yang sebelumnya digunakan memiliki beberapa kelemahan, diantaranya yaitu waktu pemrosesan training yang cenderung lama, dan akurasi yang kurang bagus [7]. Beberapa penelitian analisis sentimen yang menggunakan deep learning diantaranya adalah, penelitian yang dilakukan oleh Yoon Kim (2014) yang menggunakan arsitektur CNN (Convolution Neural Network) untuk melakukan klasifikasi sentimen. 
Penelitian ini menguji beberapa model yang dibangun pada beberapa dataset, yaitu dataset movie review, dataset stanford sentiment treebank dengan 5 kelas dan 2 kelas (binary labels), dataset customer review dan dataset TREC question. Selain itu, pada penelitian Yoon Kim ini juga sudah menggunakan pre-trained word2vec untuk pembuatan word-level embedding (vektor kata) yang digunakan sebagai input pada model CNN yang dibangun. Hasil akurasi terbaik yang diperoleh adalah sebesar $88.1 \%$ dengan menggunakan model CNN-Multichannel pada dataset Stanford sentiment 2 kelas. Penelitian analisis sentimen oleh Yoon Kim ini juga menjadi salah satu penelitian yang banyak digunakan sebagai referensi untuk penelitian analisis sentimen dengan menggunakan metode deep learning [8]. Penelitian analisis sentimen selanjutnya yang dilakukan oleh Hassan et al (2017), menggunakan metode deep learning yang merupakan gabungan antara model CNN dan LSTM (Long Short-Term Memory). Model yang dibangun diberi nama ConvLstm. Arsitektur ConvLstm mengganti layer pooling yang terdapat pada CNN dengan menggunakan layer LSTM. Layer LSTM digunakan untuk menjaga informasi dari input sequence kata yang relatif panjang. Model ConvLstm kemudian diuji pada 2 dataset yang berbeda yaitu dataset movie review IMDB dan dataset Stanford sentiment treebank (SSTB). Penelitian ini juga menggunakan word2vec untuk membentuk vektor kata dari dataset yang digunakan. Hasil akurasi terbaik yang diperoleh denggan menggunakan model ConvLstm adalah sebesar 88.3\% [9]. Lalu penelitian selanjutnya adalah penelitian yang dilakukan oleh Chachra et al (2017), yang menggunakan model arsitektur DCNN (Deep Convolution Neural Network). Model ini menggunakan layer convolutional yang sama dengan yang digunakan oleh Yoon Kim sebelumnya, hanya jumlah layer yang digunakan lebih banyak. Dataset yang digunakan adalah dataset twitter yang berisi 1.5 juta tweet yang sudah terlabeli positif dan negatif. Penelitian diuji pada beberapa iterasi yaitu dari interval interasi 1000 sampai 10.000 iterasi, dan memperoleh hasil akurasi terbaik sebesar $80.69 \%$ pada iterasi $9000[10]$.

Penelitian analisis sentimen yang selanjutnya adalah beberapa penelitian yang menggunakan model deep learning, serta melakukan analisis mengenai pengaruh dari perubahan ukuran dimensi data terhadap hasil akurasi yang diperoleh. Penelitian yang pertama adalah penelitian oleh Zheng et al (2015) yang menggunakan model arsitektur DNN (Deep Neural Network). Penelitian ini menggunakan 3 jenis dataset, yaitu dataset movie review IMDB, dataset review produk amazon, dan dataset review hotel. Pengujian dilakukan dengan menggunakan beberapa ukuran dimensi data feature, yaitu pada rentang ukuran antara 200 - 5000. Hasil dari model DNN dibandingkan dengan metode SVM dan Nä̈ve bayes, dan menunjukkan bahwa model DNN memiliki hasil akurasi yang lebih baik. Lalu ukuran dimensi data juga mempengaruhi hasil akurasi yang diperoleh [11]. Penelitian oleh Rahul et al (2016) menggunakan gabungan layer RBM (Restricted Boltzmann Machine) dan PNN (Probabilistic Neural Network). Kedua layer memiliki peran yang berbeda, layer RBM digunakan untuk ekstraksi pengurangan dimensi data, dan layer PNN digunakan untuk melakukan klasifikasi sentimen. Model diuji pada beberapa dataset yaitu dataset movie review, dataset multi domain, dan dataset review buku. Ukuran dimensi data yang diuji diantaranya adalah ukuran 50, 60, 70, 80, dan 100. Penelitian yang dilakukan bertujuan untuk mengetahui pengaruh ukuran dimensi data terhadap performa dari model yang dibangun [12].

Dataset yang digunakan pada sebuah penelitian analisis sentimen bisa mempengaruhi hasil akurasi dari model deep learning yang dibangun. Ada dataset yang berupa review seperti movie review, maupun product review yang relatif memiliki sequence kata yang panjang. Ada juga dataset berupa kumpulan tweet yang cenderung lebih pendek karena memiliki batasan kata. Untuk pengolahan dataset yang memiliki sequence kata relatif panjang, memerlukan pendekatan yang berbeda. Dengan menggunakan model CNN, maka akan memerlukan jumlah layer yang lebih banyak pada arsiktektur yang dibangun [13]. Salah satu model dari deep learning RNN yaitu LSTM bisa menjadi pilihan untuk solusi pemrosesan dataset yang relatif panjang. Model LSTM mampu menangani permasalahan vanishing gradient yang umum terjadi pada pemrosesan data yang relatif panjang [14].

Pada penelitian ini akan dijelaskan hasil dari analisis sentimen pada dataset movie review yang menggunakan metode deep learning LSTM, dan juga menggunakan word2vec sebagai pembentuk vektor kata [15]. Selain itu juga dilakukan beberapa tuning parameter untuk mengetahui pengaruhnya terhadap akurasi yang dihasilkan. Tuning parameter tersebut diantaranya yaitu menggunakan beberapa ukuran vektor kata sebagai input deep learning dan juga membandingkan penerapan 2 metode CBOW dan Skip-Gram word2vec pada proses pembentukan vektor. Paper ini terdiri dari pendahuluan, metode penelitian, hasil dan diskusi, dan kesimpulan. Bagian kedua akan menjelaskan metode penelitian yang digunakan pada penelitian ini.

\section{METODOLOGI PENELITIAN}

\subsection{Tahapan Penelitian}

Tahapan penelitian yang dilakukan terdiri dari kajian pustaka, perancangan arsitektur deep learning LSTM, persiapan dataset untuk pembentukan corpus dan training word vector, pembagian dataset untuk training dan testing model LSTM, training dengan model LSTM dan evalusi hasil, serta tahapan terakhir adalah analisa dan pembahasan. Gambar 1 di bawah merupakan alur tahapan penelitian secara detail. 
ISSN 2614-5278 (media cetak), ISSN 2548-8368 (media online)

Available Online at https://ejurnal.stmik-budidarma.ac.id/index.php/mib DOI 10.30865/mib.v5i3.3111

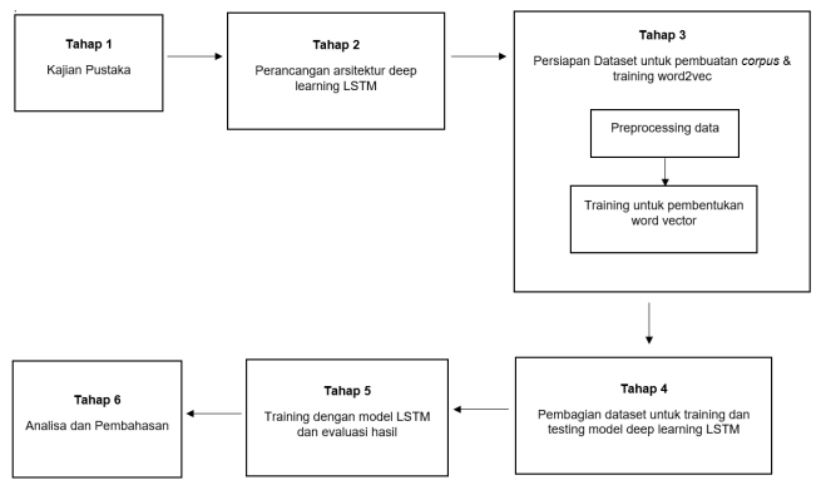

Gambar 1. Tahapan Penelitian

\subsubsection{Kajian Pustaka}

Penelitian dengan topik analisis sentimen menjadi salah satu penelitian yang populer. Ketersediaan data teks yang melimpah serta kebutuhan berbagai pihak mengenai pendapat publik terhadap suatu topik tertentu menjadi alasannya. Penelitian analisis sentimen banyak dilakukan dengan menggunakan metode machine learning seperti Lexicon based, Nä̈ve Bayes, Maximum Entropy maupun metode SVM [1], [3][16]. Metode SVM menjadi metode machine learning yang memiliki akurasi yang lebih baik pada beberapa penelitian analisis sentimen [4]-[6].

Deep learning pada penelitian analisis sentimen mulai makin banyak digunakan karena beberapa alasan, salah satunya adalah keterbatasan metode machine learning yang sebelumnya dalam memproses data dalam jumlah yang besar [7]. Beberapa penelitian analisis sentimen yang menggunakan metode deep learning, memiliki hasil akurasi yang baik di atas $80 \%$, diantaranya adalah yang menggunakan metode CNN [8], gabungan CNN dan LSTM [9] [17] [18], serta DCNN[10]. Untuk meningkatkan akurasi, beberapa penelitian analisis sentimen menggunakan word2vec sebagai model untuk membentuk word vector dari setiap kata [8]-[10], serta mencoba beberapa variasi ukuran dimensi vektor kata untuk mengetahui pengaruhnya terhadap hasil akurasi yang dihasilkan [11], [12].

\subsubsection{Perancangan arsitektur Deep Learning LSTM}

Metode deep learning LSTM (Long Short-Term Memory) dipilih karena beberapa pertimbangan, diantaranya adalah LSTM memiliki akurasi yang baik untuk data berupa teks, serta LSTM merupakan pengembangan dari metode deep learning RNN yang memiliki kelebihan mampu memproses data yang relatif panjang (long-term dependency) [19], [20]. Gambar 2 di bawah menunjukan perbedaan struktur antara model RNN dan LSTM.

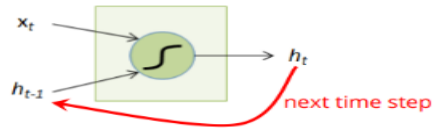

(a) RNN

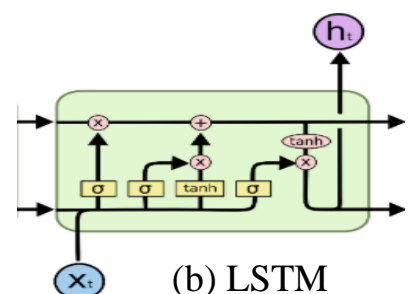

(b) LSTM

Gambar 2. Perbedaan struktur RNN dan LSTM

Seperti pada gambar 2 di atas, model RNN dan LSTM memiliki input yang sama yaitu $x_{t}$ dan $h_{t-1}$, namun fungsi untuk mengolah data di dalamnya yang berbeda. Pada model LSTM fungsi yang dimiliki lebih kompleks, terdapat 4 komponen yang berfungsi untuk mengolah data yang masuk. Keempat komponen tersebut adalah forget gate, input gate, output gate dan juga cell states. Alur proses pengolahan data yang terjadi ada model LSTM, bisa dimulai dari komponen forget gate $\left(f_{t}\right)$. Pada bagian ini, input yang diproses akan diolah dengan ketentuan sebagai berikut, informasi yang kurang dibutuhkan atau tidak terlalu memiliki makna akan dihilangkan. Input data pada komponen ini adalah data $x_{t}$ (vektor input $x$ pada timestep $t$ ) dan $h_{t-1}$ (vektor hidden state pada timestep sebelumnya $t-1)$.

$$
f_{t}=\sigma\left(W_{f} \cdot\left[h_{t-1}, x_{t}\right]+b_{f}\right)
$$

Lalu yang selanjutnya, proses pengolahan informasi masuk ke bagian input gate $\left(i_{t}\right)$. Pada bagian ini, informasi dipilah dan ditentukan informasi mana yang akan diupdate ke bagian cell states, prosesnya menggunakan fungsi aktivasi sigmoid. Pada step ini sekaligus dilakukan pembuatan kandidat vektor baru untuk ditambahkan ke bagian cell state $\left(C_{t}^{\sim}\right)$.

$$
\begin{aligned}
& i_{t}=\sigma\left(W_{i} \cdot\left[h_{t-1}, x_{t}\right]+b_{i}\right) \\
& C_{t}^{\sim}=\tanh \left(W_{C} \cdot\left[h_{t-1}, x_{t}\right]+b_{C}\right)
\end{aligned}
$$


ISSN 2614-5278 (media cetak), ISSN 2548-8368 (media online)

Available Online at https://ejurnal.stmik-budidarma.ac.id/index.php/mib DOI 10.30865/mib.v5i3.3111

Yang selanjutnya melakukan update nilai pada cell states $\left(C_{t}\right)$ yang terbaru, dengan menggunakan nilainilai yang sudah dihitung sebelumnya.

$$
C_{t}=f_{t} * C_{t-1}+i_{t} * C_{t}^{\sim}
$$

Proses yang terarkhir di LSTM terjadi pada komponen output gate $\left(o_{t}\right)$, yang akan menghasilkan nilai output dan nilai hidden state $\left(h_{t}\right)$ yang akan digunakan pada timestep yang selanjutnya $t+1$.

$$
\begin{aligned}
& o_{t}=\sigma\left(W_{o}\left[h_{t-1}, x_{t}\right]+b_{o}\right) \\
& h_{t}=o_{t} * \tanh \left(C_{t}\right)
\end{aligned}
$$

Setelah memperoleh nilai output dan hidden state $\left(h_{t}\right)$, nilai klasifikasi sentimen bisa dihitung dengan menggunakan fungsi aktivasi sigmoid ataupun softmax.

Berikut gambar 3 adalah rancangan arsitektur dari penelitian analisis sentimen dengan model LSTM yang dikerjakan. Jumlah unit LSTM, ukuran dimensi word vector serta panjang dari input sequence yang digunakan merupakan tuning parameter yang akan dicoba dianalisis untuk menemukan hasil akurasi yang terbaik.

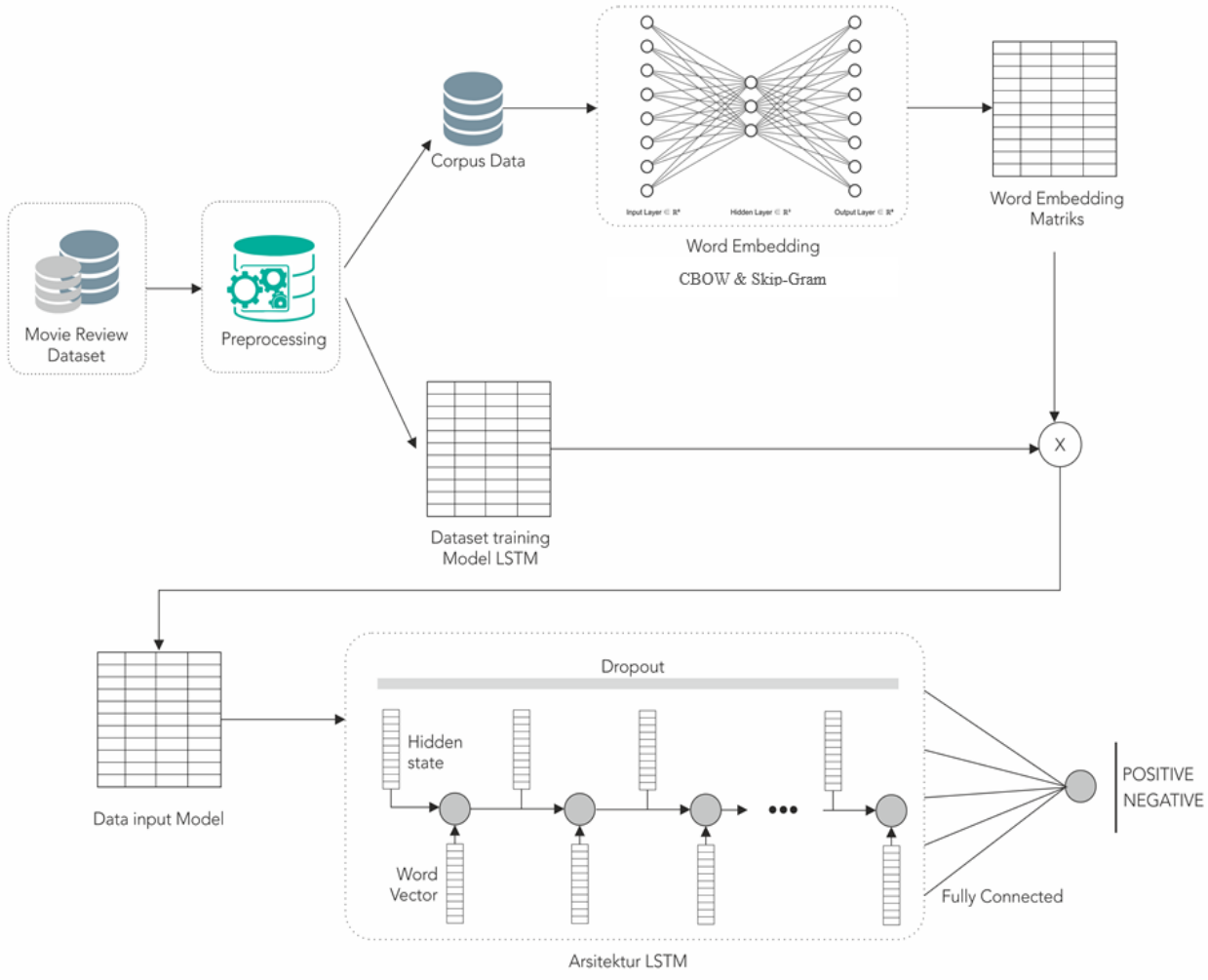

Gambar 3. Rancangan arsitektur dari penelitian analisis sentimen dengan model LSTM

\subsubsection{Persiapan Dataset}

Dataset yang digunakan pada penelitian adalah dataset movie review, yang berasal dari penelitian Andrew et al [21] (http://ai.stanford.edu/ amaas/data/sentiment/). Dataset yang digunakan berjumlah 25.000 review terdiri dari 12.500 review berlabel positif dan 12.500 review berlabel negatif. Sebelum bisa digunakan sebagai data input pada proses training model LSTM yang dibangun, maka data perlu untuk dilakukan preprocessing terlebih dahulu. Preprocessing yang dilakukan terhadap dataset ini meliputi, mengubah data ke dalam bentuk lowercase, membersihkan karakter pada review yang tidak memiliki makna sentimen, menghapus url, dan juga melakukan tokenize pada dataset. Informasi mengenai dataset movie review bisa dilihat pada tabel 1 di bawah.

Dari total 25.000 review dataset yang digunakan, terdapat sebanyak 5.844.680 kata di dalamnya. Lalu jumlah rata-rata kata per file review adalah sebanyak 233.7872 kata. Grafik persebaran untuk jumlah kata per review bisa dilihat pada gambar 4 di bawah. Dan untuk jumlah kata unik yang dimiliki oleh dataset adalah sebanyak 73.736 kata. Seluruh kata-kata ini nanti akan dijadikan sebagai corpus data untuk mengolah dan membentuk word vector dengan menggunakan model word2vec.

Tabel 1. Informasi mengenai dataset Movie Review

\begin{tabular}{ccccccc}
\hline Nama Dataset & $\begin{array}{c}\text { Jumlah Total } \\
\text { File Review }\end{array}$ & $\begin{array}{c}\text { File review } \\
\text { Positif }\end{array}$ & $\begin{array}{c}\text { File review } \\
\text { Negatif }\end{array}$ & $\begin{array}{c}\text { Jumlah Total } \\
\text { Kata }\end{array}$ & $\begin{array}{c}\text { Jumlah Kata } \\
\text { Unik }\end{array}$ & $\begin{array}{c}\text { Rata-rata kata } \\
\text { per file/review }\end{array}$ \\
\hline Movie Review & 25.000 & 12.500 & 12.500 & 5.844 .680 & 73.736 & 233.7872 \\
\hline
\end{tabular}


ISSN 2614-5278 (media cetak), ISSN 2548-8368 (media online)

Available Online at https://ejurnal.stmik-budidarma.ac.id/index.php/mib DOI 10.30865/mib.v5i3.3111

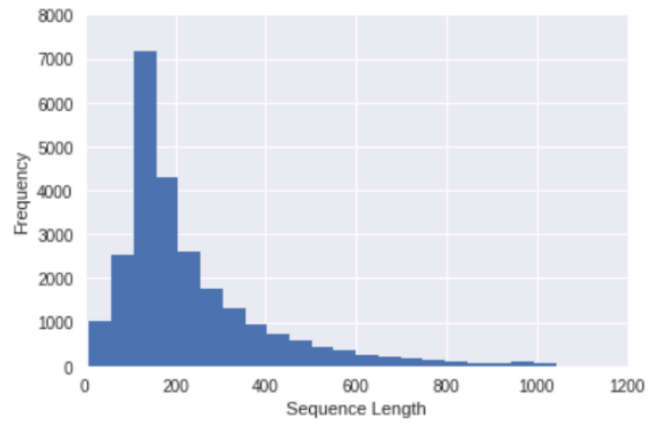

Gambar 3. Persebaran panjang kata di setiap file review

Proses pembentukan word vector pada penelitian ini menggunakan word2vec, yaitu sebuah vector representation yang dibuat oleh Google. Dengan menggunakan word2vec setiap kata dapat direpresentasikan ke dalam bentuk vektor dengan ukuran $\mathrm{N}$ dimensi tertentu .

Pada penelitian ini, corpus data yang dimiliki digunakan sebagai data input pada model word2vec. Seluruh kata pada corpus data ini nanti akan direpresentasikan ke dalam sebuah vector space dengan ukuran $\mathrm{N}$ dimensi tertentu. Setiap kata yang memiliki kesamaan makna akan terletak berdekatan pada vector space yang terbentuk [22]-[24]. Metode yang digunakan pada pembentukan representasi word vector, adalah metode CBOW (Continuous Bag of Words) dan Skip-Gram. Kedua metode ini memiliki cara kerja yang berlawanan. Perbedaan metode CBOW dan Skip-Gram bisa dilihat pada gambar 5 di bawah.
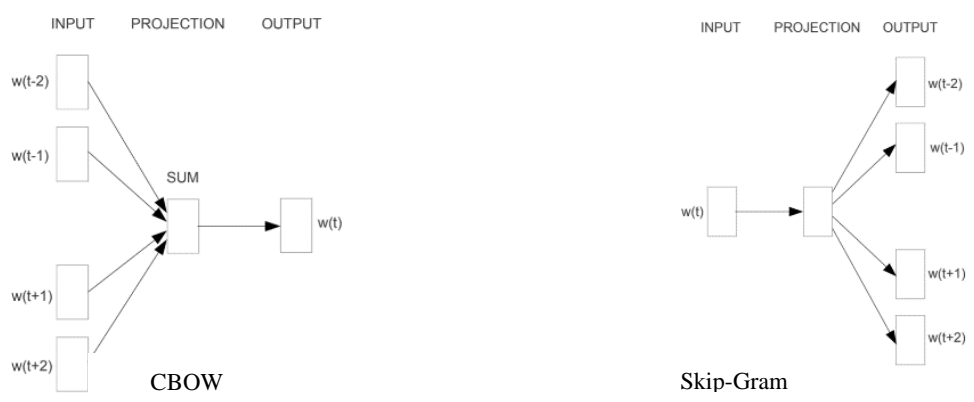

Gambar 5. Perbedaan metode CBOW dan Skip-Gram

Metode CBOW memiliki cara kerja dengan memprediksi target kata dari konteks yang dimiliki. Sedangkan pada metode Skip-Gram memiliki cara kerja yang berlawanan, yaitu dengan mencoba memprediksi konteks dari target kata yang dimiliki. Proses pembuatan word vector dapat dilihat pada gambar 6 di bawah. Sebagai contoh menggunakan metode CBOW. Nilai weight matriks ideal yang dimiliki akan dikalikan dengan vektor one-hot vector setiap kata yang dimiliki, maka akan menghasilkan word vector dari setiap kata (lihat gambar 7 di bawah)

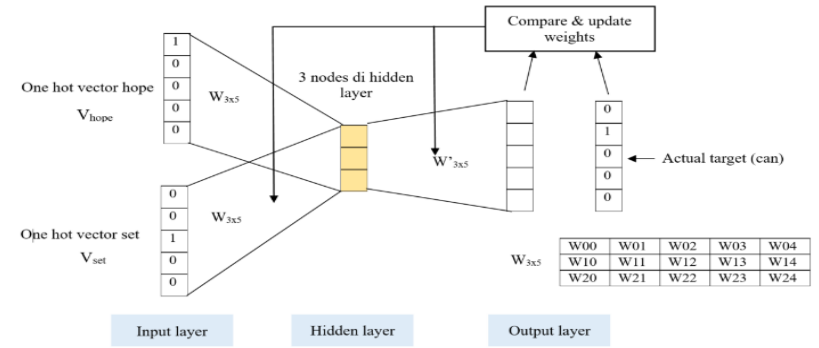

Gambar 6. Pembuatan word vector dengan CBOW

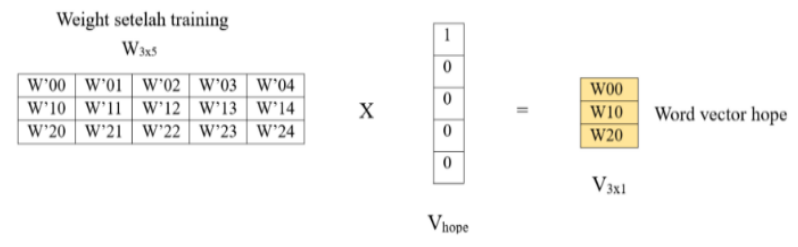

Gambar 7. Pembuatan word vector setiap kata 
ISSN 2614-5278 (media cetak), ISSN 2548-8368 (media online)

Available Online at https://ejurnal.stmik-budidarma.ac.id/index.php/mib DOI 10.30865/mib.v5i3.3111

Setelah proses pembuatan word vector dengan word2vec selesai. Maka setiap kata akan direpresentasikan ke dalam bentuk vektor di sebuah vector space. Berikut gambar 8 memperlihatkan vector space CBOW dan SkipGram dengan ukuran dimensi 50 yang digambarkan ke dalam bentuk 2 dimensi.

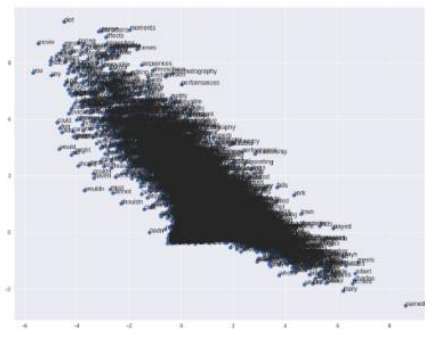

CBOW

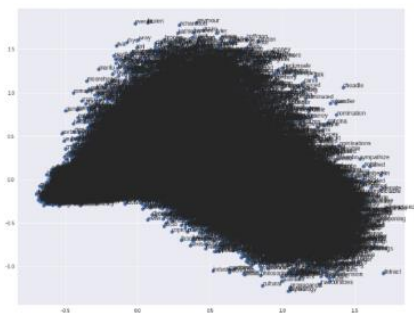

Skip-Gram

Gambar 8 Vector space CBOW dan Skip-Gram (dimensi 50) digambarkan dalam bentuk 2 dimensi

Dalam vector space tersebut, kata-kata yang memiliki makna yang mirip akan terletak berdekatan. Berikut gambar 9 di bawah memperlihatkan salah satu contoh representasi vektor (word vector) dari kata good dengan ukuran dimensi 50.

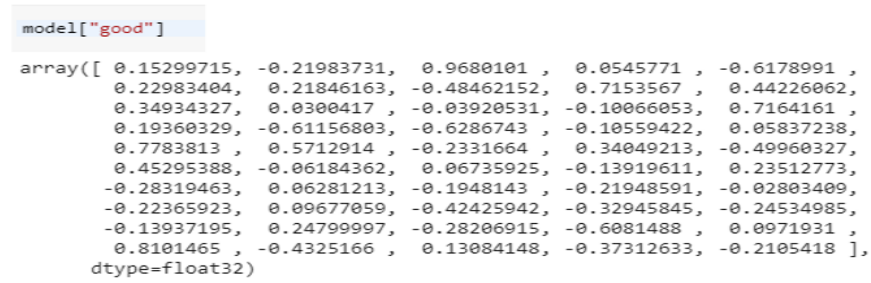

Gambar 9 Word vector dari kata good dengan ukuran dimensi 50

\subsubsection{Pembagian Dataset untuk training dan testing model LSTM}

Pembagian komposisi dataset untuk training dan testing model LSTM yang dibuat akan menggunakan rekomendasi dengan komposisi sebesar 90\%:10\% sampai dengan 80\%:20\%. Dengan catatan, porsi dataset untuk proses training yang lebih besar.

\subsubsection{Training model LSTM dan evaluasi hasil}

Pada tahap ini, selanjutnya akan dilakukan training (melatih) model LSTM yang sudah dibangun dengan menggunakan data input yang sudah disiapkan sebelumnya. Data input merupakan kumpulan vektor hasil dari tahapan preprocessing dan pembuatan word vector di tahapan sebelumnya. Alur proses training dari model LSTM ini adalah setiap kata yang sudah direpresentasikan ke dalam bentuk vektor akan dimasukkan satu per satu sesuai dengan urutan sequence-nya ke dalam model LSTM. Proses ini akan berulang sampai dengan sequence yang terakhir, setelah itu model LSTM akan menggunakan fungsi aktivasi sigmoid untuk menentukan nilai probabilitas dari sentimen review tersebut. Gambar 10 di bawah memperlihatkan proses training (melatih) dengan model LSTM.

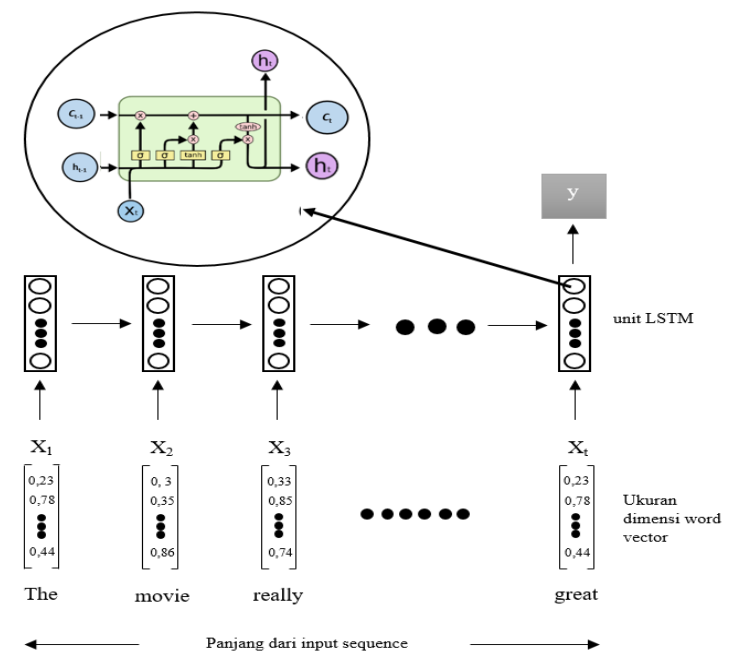

Gambar 10 Proses training dengan model LSTM 
Setiap kata yang sudah direpresentasikan ke dalam bentuk vektor (word vector) dimasukkan ke dalam unit LSTM satu per satu sesuai dengan urutan dari sequence file review. Tuning parameter dilakukan pada beberapa parameter yaitu diantaranya parameter panjang input sequence, jumlah unit LSTM yang digunakan serta ukuran dimensi word vector dari setiap input kata. Analisis akan dilakukan untuk mengetahui pengaruh dari dilakukannya tuning parameter tersebut terhadap hasil akurasi yang diperoleh dari model LSTM.

\subsubsection{Analisa dan Pembahasan}

Analisis sentimen yang dilakukan pada dataset movie review dengan menggunakan model LSTM dan word2vec, mengharapkan hasil akurasi yang setidaknya lebih dari 80\%. Model LSTM yang dibangun, serta beberapa tuning parameter yang dilakukan, ditujukkan untuk meningkatkan akurasi yang dihasilkan. Pembahasan lebih detail akan dijelaskan pada bagian hasil dan pembahasan.

\section{HASIL DAN PEMBAHASAN}

Pada bagian ini akan menjelaskan hasil dan pembahasan dari penelitian analisis sentimen yang sudah dikerjakan. Hasil evaluasi dari setiap model LSTM yang digunakan untuk melakukan klasifikasi sentimen, difokuskan pada nilai akurasinya. Tuning parameter dilakukan untuk mengetahui pengaruhnya terhadap hasil akurasi yang diperoleh. Di awal, tuning parameter yang dilakukan adalah dengan membandingkan metode pembuatan word vector dengan word2vec, dan juga membandingkan beberapa ukuran dimensi dari word vector yang terbentuk. Metode pembuatan word vector yang digunakan adalah CBOW dan Skip-Gram, dan variasi ukuran dimensi word vector yang digunakan adalah 50, 60, 100, 150, 200 dan 500 dimensi.

Selain melakukan tuning parameter awal pada tahapan penyiapan data seperti di atas, tuning parameter juga perlu dilakukan pada model LSTM yang akan digunakan. Berikut adalah tabel 2 yang menunjukan tuning parameter awal untuk model LSTM.

Tabel 2. Tuning parameter model LSTM

\begin{tabular}{ccccccc}
\hline $\begin{array}{c}\text { Jumlah unit } \\
\text { LSTM }\end{array}$ & Feature data & Epoch & Batch size & $\begin{array}{c}\text { Panjang } \\
\text { sequence } \\
\text { review }\end{array}$ & Dropout & Optimizer \\
\hline 50 & 5000 & 10 & 64 & 300 & 0.5 & Adam \\
\hline
\end{tabular}

Hasil akurasi yang diperoleh saat melakukan training pada model LSTM yang dibangun bisa dilihat padah tabel 3 di bawah. Tabel berisi perbandingan nilai akurasi dari penggunaan metode CBOW dan Skip-Gram word2vec, dan juga perbandingan akurasi di setiap ukuran dimensi word vector yang digunakan. Hasil akurasi terbaik yang bisa diperoleh dengan model LSTM adalah sebesar $88.17 \%$ pada ukuran dimensi word vector 100 , yang dibentuk dengan menggunakan metode Skip-Gram. Sedangkan untuk yang menggunakan metode CBOW, hasil akurasi terbaik sebesar 87.68\% pada ukuran dimensi word vector 200.

Tabel 3. Perbandingan akurasi antara metode Skip-Gram dan CBOW di beberapa ukuran dimensi word vector

\begin{tabular}{ccc}
\hline $\begin{array}{c}\text { Ukuran dimensi word } \\
\text { vector }\end{array}$ & $\begin{array}{c}\text { Akurasi Skip- } \\
\text { Gram }\end{array}$ & Akurasi CBOW \\
\hline 50 & $87.86 \%$ & $86.62 \%$ \\
60 & $88.04 \%$ & $86.44 \%$ \\
100 & $88.17 \%$ & $86.26 \%$ \\
150 & $88.08 \%$ & $87.46 \%$ \\
200 & $87.51 \%$ & $87.68 \%$ \\
500 & $85.86 \%$ & $86.88 \%$ \\
\hline
\end{tabular}

Dari tabel 3 di atas, hasil akurasi yang diperoleh dengan metode Skip-Gram maupun CBOW untuk di beberapa variasi ukuran dimensi word vector cenderung stabil. Rentang akurasi yang dihasilkan diantara 87.51\%88.17\% untuk metode Skip-Gram pada ukuran dimensi 50-200, dan 86.26\%-87.68\% untuk metode CBOW pada ukuran dimensi yang sama. Secara keseluruhan hasil akurasi Skip-Gram lebih baik dibandingkan CBOW untuk ukuran dimensi 50, 60, 100 dan 150. Metode CBOW unggul di ukuran dimensi word vector 200 dan 500. Namun apabila diperhatikan pada tabel di atas, ternyata ukuran dimensi yang semakin besar tidak menjamin bisa menghasilkan akurasi yang lebih baik. Hal ini bisa terjadi karena ada beberapa kemungkinan, salah satunya adalah terjadi overfitting saat melakukan training model LSTM. Berikut gambar 11 memperlihatkan grafik dari akurasi yang dihasilkan pada setiap epoch metode Skip-Gram dan CBOW. 
ISSN 2614-5278 (media cetak), ISSN 2548-8368 (media online)

Available Online at https://ejurnal.stmik-budidarma.ac.id/index.php/mib DOI 10.30865/mib.v5i3.3111
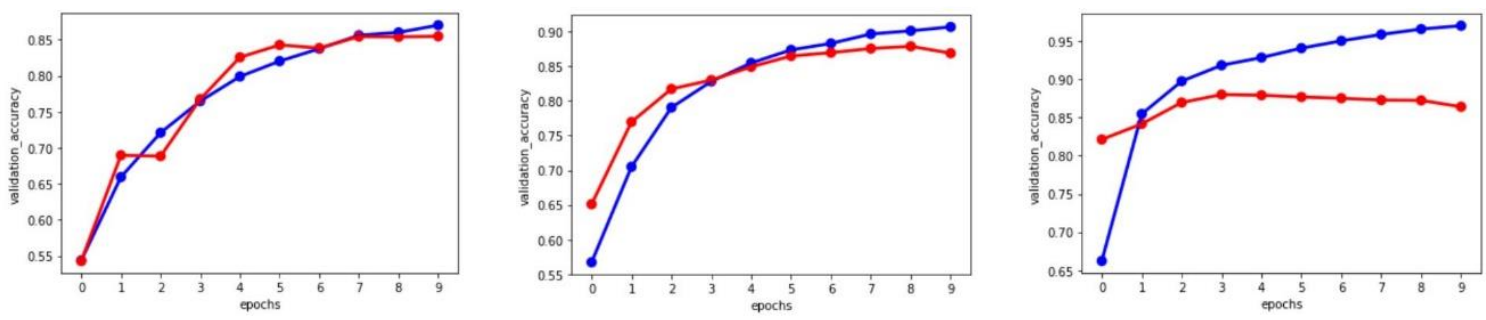

CBOW dimensi $50-100-500$
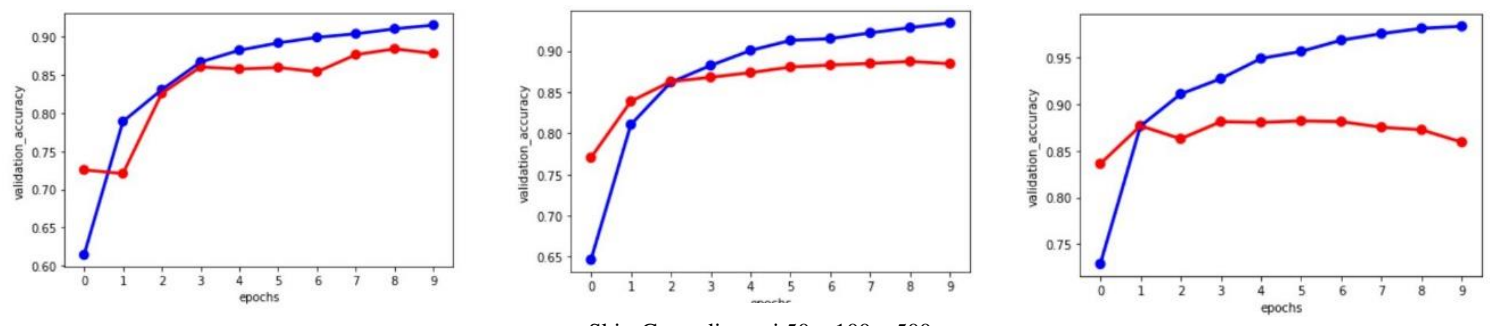

Gambar 11 Perbandingan grafik akurasi Ski-Gram dan CBOW pada ukuran dimensi 50, 100 dan 500

Pada gambar 11 di atas, garis warna biru menunjukan akurasi terhadap data training di setiap epoch. Sedang garis warna merah adalah validasi akurasi yang diperoleh dengan menggunakan data testing. Dari grafik di atas, untuk word vector di ukuran dimensi 50,100 memiliki validasi akurasi yang cukup stabil. Sedangkan pada dimensi 500, nilai validasi akurasinya cenderung menurun di epoch 9 ke atas, ini bisa menandakan terjadi overfitting pada model yang dilatih.

Selain melakukan analisa pada hasil akurasi di setiap epoch, analisa juga dilakukan pada waktu training yang diperlukan saat melatih model LSTM. Hasil menunjukan semakin besar ukuran dimensi word vector yang digunakan, maka waktu training yang diperlukan pun juga semakin lama. Nilai akurasi dan juga lamanya waktu training sering digunakan sebagai indikasi penilaian performa dari sebuah metode machine learning.

\section{KESIMPULAN}

Penelitian analisis sentimen yang menggunakan metode deep learning LSTM dan word2vec untuk pembentukan word vector, telah berhasil dikerjakan. Hasil akurasi yang diperoleh paling sedikit ada pada angka 85.86\%, yang artinya cukup bagus dalam melakukan klasifikasi sentimen. Sehingga metode LSTM dengan word2vec bisa menjadi salah satu pilihan ketika ingin melakukan penelitian mengenai analisis sentimen dengan data dalam jumlah yang besar. Dari hasil pembahasan di atas, masih ada beberapa tuning parameter yang bisa coba dilakukan untuk meningkatkan hasil akurasi model LSTM yang dibangun. Beberapa tuning parameter tersebut adalah mencoba variasi jumlah unit LSTM yang digunakan, lalu ukuran feature data yang dibentuk, jumlah epoch, nilai dropout yang digunakan, serta ukuran panjang sequence data yang diproses.

\section{REFERENCES}

[1] W. Medhat, A. Hassan, and H. Korashy, "Sentiment analysis algorithms and applications: A survey," Ain Shams Eng. J., vol. 5, no. 4, pp. 1093-1113, 2014, doi: 10.1016/j.asej.2014.04.011.

[2] K. Ravi and V. Ravi, A survey on opinion mining and sentiment analysis: Tasks, approaches and applications, vol. 89 , no. June. Elsevier B.V., 2015.

[3] P. Baby and K. B, "Sentimental Analysis and Deep Learning: A Survey," Int. J. Sci. Res. Sci. Eng. Technol., pp. 212 220, 2020, doi: 10.32628/ijsrset207135.

[4] K. Saranya and S. Jayanthy, "Onto-based sentiment classification using machine learning techniques," Proc. 2017 Int. Conf. Innov. Information, Embed. Commun. Syst. ICIIECS 2017, vol. 2018-Janua, pp. 1-5, 2018, doi: 10.1109/ICIIECS.2017.8276047.

[5] Y. Dang, Y. Zhang, and H. Chen, "A lexicon-enhanced method for sentiment classification: An experiment on online product reviews," IEEE Intell. Syst., vol. 25, no. 4, pp. 46-53, 2010, doi: 10.1109/MIS.2009.105.

[6] M. Rushdi Saleh, M. T. Martín-Valdivia, A. Montejo-Ráez, and L. A. Ureña-López, "Experiments with SVM to classify opinions in different domains," Expert Syst. Appl., vol. 38, no. 12, pp. 14799-14804, 2011, doi: 10.1016/j.eswa.2011.05.070.

[7] G. Adam and P. Josh, Deep Learning: A Practitioner's Approach. 2017.

[8] Y. Kim, "Convolutional neural networks for sentence classification," EMNLP 2014 - 2014 Conf. Empir. Methods Nat. Lang. Process. Proc. Conf., pp. 1746-1751, 2014, doi: 10.3115/v1/d14-1181.

[9] A. Hassan and A. Mahmood, "Deep Learning approach for sentiment analysis of short texts," 2017 3rd Int. Conf. Control. Autom. Robot. ICCAR 2017, pp. 705-710, 2017, doi: 10.1109/ICCAR.2017.7942788. 
[10] A. Chachra, P. Mehndiratta, and M. Gupta, "Sentiment analysis of text using deep convolution neural networks," 2017 10th Int. Conf. Contemp. Comput. IC3 2017, vol. 2018-Janua, no. August, pp. 1-6, 2018, doi: 10.1109/IC3.2017.8284327.

[11] Z. Hu, J. Hu, W. Ding, and X. Zheng, "Review Sentiment Analysis Based on Deep Learning," Proc. - 12th IEEE Int. Conf. E-bus. Eng. ICEBE 2015, pp. 87-94, 2015, doi: 10.1109/ICEBE.2015.24.

[12] R. Ghosh, K. Ravi, and V. Ravi, "A novel deep learning architecture for sentiment classification," 2016 3rd Int. Conf. Recent Adv. Inf. Technol. RAIT 2016, pp. 511-516, 2016, doi: 10.1109/RAIT.2016.7507953.

[13] X. Zhang, J. Zhao, and Y. Lecun, "Character-level convolutional networks for text classification," Adv. Neural Inf. Process. Syst., vol. 2015-Janua, pp. 649-657, 2015.

[14] M. Sundermeyer, H. Ney, and R. Schluter, "From feedforward to recurrent LSTM neural networks for language modeling," IEEE Trans. Audio, Speech Lang. Process., vol. 23, no. 3, pp. 517-529, 2015, doi: 10.1109/TASLP.2015.2400218.

[15] R. Ni and H. Cao, "Sentiment Analysis based on GloVe and LSTM-GRU," Chinese Control Conf. CCC, vol. 2020-July, pp. 7492-7497, 2020, doi: 10.23919/CCC50068.2020.9188578.

[16] A. H. Quraishi, "Performance analysis of machine learning algorithms for Movie Review," Int. J. Comput. Applivations, vol. 177, no. 36, pp. 1-4, 2020, doi: 10.4018/IJHISI.2020040101.

[17] A. Yenter and A. Verma, "Deep CNN-LSTM with combined kernels from multiple branches for IMDb review sentiment analysis," 2017 IEEE 8th Annu. Ubiquitous Comput. Electron. Mob. Commun. Conf. UEMCON 2017, vol. 2018-Janua, pp. 540-546, 2017, doi: 10.1109/UEMCON.2017.8249013.

[18] N. Hossain, M. R. Bhuiyan, Z. N. Tumpa, and S. A. Hossain, "Sentiment Analysis of Restaurant Reviews using Combined CNN-LSTM," 2020 11th Int. Conf. Comput. Commun. Netw. Technol. ICCCNT 2020, 2020, doi: 10.1109/ICCCNT49239.2020.9225328.

[19] A. Hassan and A. Mahmood, "Convolutional Recurrent Deep Learning Model for Sentence Classification," IEEE Access, vol. 6, no. c, pp. 13949-13957, 2018, doi: 10.1109/ACCESS.2018.2814818.

[20] X. Wang, W. Jiang, and Z. Luo, "Combination of convolutional and recurrent neural network for sentiment analysis of short texts," COLING 2016 - 26th Int. Conf. Comput. Linguist. Proc. COLING 2016 Tech. Pap., pp. 2428-2437, 2016.

[21] A. L. Maas, R. E. Daly, P. T. Pham, D. Huang, A. Y. Ng, and C. Potts, "Learning word vectors for sentiment analysis," ACL-HLT 2011 - Proc. 49th Annu. Meet. Assoc. Comput. Linguist. Hum. Lang. Technol., vol. 1, pp. 142-150, 2011.

[22] T. Mikolov, I. Sutskever, K. Chen, G. Corrado, and J. Dean, "Distributed representations ofwords and phrases and their compositionality," Adv. Neural Inf. Process. Syst., pp. 1-9, 2013.

[23] T. Mikolov, K. Chen, G. Corrado, and J. Dean, "Efficient estimation of word representations in vector space," 1st Int. Conf. Learn. Represent. ICLR 2013 - Work. Track Proc., pp. 1-12, 2013.

[24] T. Mikolov, W. T. Yih, and G. Zweig, "Linguistic regularities in continuous spaceword representations," NAACL HLT 2013 - 2013 Conf. North Am. Chapter Assoc. Comput. Linguist. Hum. Lang. Technol. Proc. Main Conf., pp. 746-751, 2013. 